\title{
The Dynamics of Globalization in the Regional Film The Chanters Mary Anne Mallari
}

\begin{abstract}
Globalization affects specific regions in the Philippines both in positive and adverse ways. While it brings in capital from migrant laborers and more advanced communication technology to connect remote regions to highly urbanized areas, globalization also causes the disenfranchisement of natives and their cultures. Its effect on ethnic cultures is clearly seen in James Robin Mayo's The Chanters (Cena, Nazareno, Lapuz, \& Mayo, 2017), a regional film about a young girl named Sarah Mae, a member of an ancient PanayBukidnon tribe too engrossed in globalized influences that she almost forgets the importance of her ethnic culture, as seen in her treatment of her grandfather Ramon, one of the few living chanters of their tribe. Using the aforementioned film, this paper attempts to explain the development of globalization in rural areas using Appadurai's theory of global cultural flows. In addition, this paper will discuss how the effect of globalization in rural communities is analogous to the development of regional films, using Deleuze and Guattari's concept of a rhizomatic growth found in A Thousand Plateaus: Capitalism and Schizophrenia (1987). Ultimately, this type of development of regional films, with the aid of globalization, leads to a greater appreciation of the cultures in the regions and proves that the regions are an integral part of the nation.
\end{abstract}

Keywords: Philippine regional films, globalization, rhizomatic development, Appadurai, Deleuze and Guattari 


\section{Plaridel Open Access Policy Statement}

As a service to authors, contributors, and the community, Plaridel: A Philippine Journal of Communication, Media, and Society provides open access to all its content. To ensure that all articles are accessible to readers and researchers, these are available for viewing and download (except Early View) from the Plaridel journal website, provided that the journal is properly cited as the original source and that the downloaded content is not modified or used for commercial purposes. Plaridel, published by the University of the Philippines College of Mass Communication is licensed under Creative Commons Attribution-NonCommercial-NoDerivatives 4.0 International License (https://creativecommons.org/ licenses/by-nc-nd/4.0/legalcode).

\section{How to cite this article in APA}

Mallari, M. A. (2020). The dynamics of globalization in the regional film The Chanters. Plaride, 17(2), 1-21. http://www.plarideljournal.org/article/the-dynamics-of-globalization-in-the-regional-film-thechanters/ 
Regional films are cultural productions that defy the Manila-centric notion of artistic creation. Digital technology ushered the creation of regional filmmaking (Hernandez, 2014, p. 49), which uses the foreign art of cinema to expose the audience to the world of the native Filipinos through the portrayal of their specific narratives. These regional narratives are quite diverse and remind us that the native Filipinos are important voices that also constitute to the essence of the nation.

The term "regional film" is often used in cinematic language today and Teddy Co (1987), in his article, "In Search of Philippine Regional Cinema," was one of the first film critics who mentioned its importance, saying that Philippine cinema becomes a "dynamic social force" once more diverse narratives are introduced (p. 20). About two decades later, regional filmmaking was promoted through the organization of Cinema Rehiyon in 2008 by the National Commission for Culture and the Arts (NCCA), aiming to "exhibit cinematic works from the various regions of the Philippines outside Metro Manila, as well as to encourage creative production in those areas as a way of decentralizing artistic activity in the Philippines" (Groyon, 2014, p. 177).

Miguel Rapatan (2017) noted that the term "regional cinema" is attributed to different contexts, namely, geographical, ethnolinguistic, thematic, or professional. Rapatan mentioned that the geographical dimension of regional filmmaking refers to the filmmaker's "geographical origin by birth," while the ethnolinguistic context considers "language as a vital component where nuanced expressions suggest distinct worldviews or reflect a unique character" (p. 82). In this context, language describes the cultural milieu of the region in which it is spoken. The thematic context, on the other hand, indicates the specifics of a local culture outside Manila, regardless of the ethnicity of the director or the actors, and the language that the film uses. In this case, National Artist for Film Lamberto Avellana's Badjao (De Leon \& Avellana, 1957), which talks about the travelling cultures of the Mindanaoan tribe, and Ida del Mundo's K'na the Dreamweaver (De Leon, De Castro, \& Del Mundo, 2014), which portrays the indigenous tribe of the T'bolis, may be considered regional films even though the directors and most of the cast do not belong to the tribes which they portray. Lastly, the professional context of a regional film refers to the place where the filmmaker has worked in the entirety of his career. What is important here is that the filmmaker is thoroughly familiar with the culture of that locality, enough for him to create a movie that depicts that particular region.

In addition to these aforementioned points, Rapatan (2017) also said that it is also imperative to consider the film's "verisimilitude as a way of measuring a film's integrity and authenticity" (p. 83) before it could be called 
an example of regional cinema. It is important to scrutinize whether the film presents truthful depictions of the culture it deals with. Authenticity in the representations of the narratives is key in the creation of regional films. Here, the notion of 'regional', although overlapping, requires a filmmaker's connection to the particular place whose culture he wants to depict.

Regional films are crucial cultural elements because they promote the diverse cultures of various Philippine localities. However, as filmmaker JP Carpio says, "Metro Manila filmmakers, even those with regional origins, are not adequately exploring the cultures of Filipinos living outside Metro Manila. Thus, Metro Manila perspectives continue to dominate" (as cited in Hernandez, 2014, p. 51). This openness to the influences of highly urbanized cities of the country and to foreign cultures is an effect of globalization, defined as the "intensification of worldwide social relations which link distant localities in such a way that local happenings are shaped by events occurring many miles away and vice versa" (Giddens, 1990, p. 64). The effect of globalization manifests not only in the Filipino spectators' preference for Manila-centric mainstream films or superhero action Hollywood movies but also in other aspects as well. It strengthens tourism in most parts of the country. For example, cities such as Baguio, Cebu and Davao, which are also highly industrialized, have a different allure for tourists who wish to explore the fusion of tradition and modernity. Yet globalization also brings more problems, especially to local ethnic cultures, which are overshadowed by modern influences.

Cultural anthropologist Arjun Appadurai has contested this top-down approach in viewing globalization, stating that it may also emerge from the margins. Using the terms "grassroots globalization" and "globalization from below," Appadurai (2001) asserted the importance of looking at globalization from a bottom-up approach, saying that this type "strives for a democratic and autonomous standing in respect to various forms by which global power further extends its dominion" (p. 3). Appadurai's grassroots globalization may be applied to the creation, as well as the audiences' reception, of regional film production. While we often think that globalization only entails influences of urbanized centers on localities, it is also essential to note that the production of regional films and their achievements in both national and international film festivals show that these films may also shape the way the world perceives the Filipinos and their country, changing the dynamics of globalization.

Furthermore, Appadurai (1996) said that the influences brought about by globalization are also actively utilized by local groups, which are always thought of to be at the receiving end. For him, the globalized economy is complex, and it "cannot any longer be understood in terms of 
existing center-periphery models" (p. 32). Applying this thought to artistic productions, the creation of films outside Manila-centric societies is a must since these regional films encourage a type of globalization that specifically bolsters local cultures and promotes their advancement, rather than merely concentrating on Manila or Hollywood productions.

The same dynamics of globalization that Appadurai explains are illustrated in James Robin Mayo's film The Chanters (Cena, Nazareno, Lapuz, \& Mayo, 2017). The film depicts the story of Sarah Mae, a teenage girl belonging to an ancient tribe of chanters in the Panay-Bukidnon region. She almost does not realize the importance of her own culture because of the effects of globalization in her community. Sarah Mae prefers to watch her favorite telenovela or try out the latest dance moves with her friends rather than learn the traditional chant from her grandfather, Ramon, who is one of the few living chanters of their tribe. The aging Ramon shows signs of senility, so he transcribes the Sugidanon chants for the NCCA while he still remembers them. The threat of forgetting the Panay culture is partly brought about by generational differences and also by the fact that the Panay locality is also changed by globalization. And towards the end of the film, Sarah Mae changes her perspective about her ethnic roots and decides to promote her culture to her own community, mainly by contemporizing it so that younger generations may appreciate their culture more.

As mentioned, this paper will explain the dynamics of globalization using Appadurai's theory on the dimensions of global cultural flows, in which he utilizes the idea of the landscape to explore the effects of globalization in a general context. The dynamics of globalization will also be related to the notion of rural space as a rhizome, an idea explained by Deleuze and Guattari in A Thousand Plateaus: Capitalism and Schizophrenia (1987). The rhizome grows in a lateral fashion, blurring origins or centralities, unlike a tree, which branches out vertically, exemplifying hierarchies. Using the metaphor of the rhizome to stand for the development of regional films and culture, this paper attempts to show how the growth of regional films also parallels the development of globalization in regional cultures.

\section{Regional Film as Rhizome}

Philosophers Deleuze and Guattari, in the first chapter of their work $A$ Thousand Plateaus (1987), elaborated on the concept of a rhizome. They stated that "any point of the rhizome can be connected to anything other, and must be" (p. 7). The botanical rhizome, such as a potato or ginger, grows from other rhizomes that then produces independent sprouts. This is different from trees that branch out into different leaves or fruits, its growth still dependent on one source. Once a tree is uprooted or cut, it may no 
longer grow, unlike a rhizome, which has grown other shoots independent of its origin. The image of the rhizome can be related to the importance of plurality in cultural productions outside the boundaries of Manila, seen in the increase in the number of Philippine regional films today. The network of connections established by regional films and their inclusion in film festivals may be compared to "an assemblage [that] is precisely this increase in the dimensions of a multiplicity that necessarily changes in nature as it expands it connections" (p. 8). As mentioned earlier, the establishment of Cinema Rehiyon allowed filmmakers from the regions to promote their works in other parts of the country as well, including Manila, "as a way of decentralizing artistic activity in the Philippines (Groyon, 2014, p.117). Other film festivals followed suit, accepting films from directors coming from the different Philippine regions so that their works may be exhibited in theaters. These festivals provide an avenue for filmmakers to show the richness of culture outside Manila. Cinemalaya, the most popular film festival for independent films, also includes regional films in their annual list for viewing. The Junior Chamber International Philippines, commonly known as Philippine Jaycees, hosts the annual "Outstanding Farmer of the Philippines," and recently, they had organized To Farm Film Festival, which includes films set in agricultural spaces, with themes centering on the socioeconomic conditions of farmers. Cinema One Originals, a film festival by the media conglomerate ABS-CBN, also provides opportunities for regional directors. Films that have been part of this film festival include Remton Siega Zuasola's Ang Damgo ni Eleuteria (Arguelles, Borlasa, \& Zuasola, 2010), which portrays the life of Terya, a young woman forced to become a mail-order bride to pay the family debts; Richard Somes's Yanggaw (Agruelles, Montelibano, \& Somes, 2008), a reinterpretation of the aswang myth told through the story of a young woman who contracts a disease and turns into the horrifying monster; and Arnel Mardoquio's Ang Paglalakbay ng mga Bituin sa Gabing Madilim (Canedo, Cejeco, \& Mardoquio, 2012), a film which poetically interprets the ravages of the war in Mindanao. QCinema, an international film festival organized by the local government of Quezon City, gives opportunities for Filipinos and foreigners alike to showcase their films for a week.

We can also see that regional films develop like a rhizome because they are produced in different parts of the country-comparable to how a rhizome grows in different directions. Once they have borne fruit, these new rhizomes become independent of their origins. Deleuze and Guattari's (1987) notion of the rhizome is also comparable to the diverse themes of regional films. As they have mentioned, "multiplicities are rhizomatic and expose arborescent pseudomultiplicities for what they are" (p. 8). The idea 
of 'pseudomultiplicities', or false multiplicities, may be applied in the context of cinematic themes. Relating this to regional films, most films produced in Manila, except perhaps the art films, are just formulaic, emulated from Hollywood. Numerous films continue to be produced, but these films are just mimicries of the previous ones. This may be related to what Deleuze and Guattari calls "pseudomultiplicities"-Philippine cinema appears to have reconceptualized earlier thematic formulas but, in reality, has not. On the other hand, the multiplicities shaped by regional films may indeed be called true multiplicities because not only did they develop in different regions, but their themes are also distinct from one another, with the narratives authentically portraying the stories of each Philippine locality.

For example, National Artist Kidlat Tahimik (Eric de Guia in real life) has been narrating stories of his native hometown Baguio in most of his films, proving that he "has been filming from the regions without the benefit or limitations of the now oft-used term 'regional cinema', institutionalized in 2009 as the state-supported film festival, Cinema Rehiyon, and without the burden of differentiating against the Manila-centric film industry" (Campos, 2016, p. 173). For E. San Juan (2000), Kidlat Tahimik's style reflects a "mixed and unevenly developed practice which, for the most part, stimulates critical reflection by techniques of displacement and distantiation" (p. 276). Employing the mixture of the experimental film and the narrative film, Kidlat Tahimik's works often criticize neocolonialism's effect on the indigenous groups.

Regional films from Luzon such as Petersen Vargas's 2 cool 2 be 4gotten (Ang, Arguelles, Grande \& Vargas, 2016), Zig Dulay's Paglipay (How \& Dulay, 2016), and Carlo Enciso Catu's Ari: My Life with a King (Lapuz, Mendoza, Aniceto, Tantingco, Baltazar, \& Catu, 2015) all present Luzon as a region where native and foreign-usually American-influences continuously contradict one another, with the latter gaining more ground. 2 cool 2 be 4gotten is the bildungsroman or coming-of-age story of Felix, a Pampanga native, who thinks of himself as superior to his classmates, though he lacks social skills. He meets the Filipino-American Snyder brothers, Magnus and Maxim, who are transferees from another school. Their American father had abandoned their mother, a former prostitute, but promises to take them with him to America after they finish high school in the Philippines. Set in the late 1990s, this film shows most of Pampanga covered in ash because of the eruption of Mount Pinatubo in 1991, and this signifies a region struggling to maintain its Kapampangan language and culture amidst the phenomenon of globalization. Carlo Enciso Catu's 2015 film Ari: My Life with a King, which is also a bildungsroman narrative set in Pampanga, also tackles the same theme. The main character Jaypee is 
tasked to fetch a local poet laureate named Tatang Haspe from his home for a local school program. Tatang Haspe is one of the recipients of a special alumni award from his high school institution, and he is asked to deliver a poem, which most of the young and old people impassively listen to. Catu's film shows the beauty of Kapampangan language through its local poetry but also the quickly diminishing heritage being replaced by a modern and Americanized way of life. On the other hand, Zig Dulay's Paglipay (2016) talks about the culture of the Aetas using the romance genre. Atan, a young Aeta native, is engaged to be married to his childhood friend Ati. Following tradition, Atan is tasked to give Ati a dowry, and he works hard for it. However, during one of his trips to the village marketplace, he meets Rain, a University of the Philippines student who is researching on the intermarriages of the kulot and the unat among the Zambales tribes, and is smitten with her. Interspersed with the love triangle are cultural and socioeconomic discussions prevalent in the Aeta community, such as the threat of mining and the highland culture of the Aetas being overpowered by the lowland and Manila way of life.

The films from the Visayas region shows the native culture being revered by the community but with neocolonial forces attempting to push it into oblivion. For example, Kristian Cordero's Hinulid (Factora, Petronas, \& Cordero, 2016) weaves the sorrowful narrative of a mother who loses her son to a frat killing with the tale of Three Christs, a popular Bicolano folk story. Nora Aunor plays the steadfast mother who wants justice to be served for her lost son, but the end of the film lets us contemplate on whether memory is more important than justice. Remton Siega Zuasola's Soap Opera (Arguelles, Balbuena, \& Zuasola, 2014) tells two narratives. The first narrative is the story of con artists, a husband and his wife, who tries to extort money from a foreigner via an online dating service so that they may give their child a better life. This narrative is juxtaposed with the drama happening in the soap operas they have been watching. The movie explores the theme of neocolonial influences and is reminiscent of his earlier film, Ang Damgo ni Eleuteria (2010), which talks about a mail-order bride in the island of Olango, Cebu.

Mindanaoan films also tackle the conflict between native and urban cultures, but there is more focus on the armed conflict in the Southern Philippine regions, which largely disenfranchises cultural minorities. Sheron Dayoc's Women of the Weeping River (Aiothouna, Dayoc, Micoulet, Thoke, \& Dayoc, 2016) interrogates the issue of clan wars in Mindanao, which are rooted in the problem of land grabbing among the members of the community. This issue is also compared with the ongoing military conflict in the same regions, which also poses a grave threat to the locals. 
Meanwhile, the displacement of the lumad is narrated in Arbi Barbarona's Tu Pug Imatuy (Barbarona, Macusang, Mardoquio, Mendez, \& Tolentino, 2017), which tells the story of a Lumad couple arrested by the military after being suspected to be NPA rebels. The film shows how the ongoing armed conflict in Mindanao ruins the lives of innocent minorities.

All the aforementioned regional films exemplify a wide variety of themes, and such diversity is comparable to the multiplicities illustrated by the growth of a rhizome. The themes include how globalization affects communities, whether in positive or negative ways. The development brought about by globalization is first discussed by Arjun Appadurai in his essay, "Disjuncture and Difference in the Global Cultural Economy," (first published in 1990) which later became a part of his larger work, Modernity at Large (1996). In the larger work, Appadurai stated that "the new global cultural economy has to be seen as a complex, overlapping, disjunctive order that can no longer be understood in terms of existing center-periphery models" (p. 32). This idea is also in conjunction with the Deleuze and Guattari's (1987) notion of the rhizome, wherein the line between center and periphery is already blurred.

According to Appadurai, global cultural flows may be seen in five different dimensions, and he used the idea of the landscape-ethnoscapes, mediascapes, technoscapes, financescapes, and ideoscapes - as a key image in explaining globalization. Ethnoscapes refer to the "landscape of persons," whereby there is an increase in people's mobility as they travel from one place to another because of work or other reasons. Technoscapes are the systems into which technology grows and is utilized. Financescapes refer to the movement of money associated with the developments in the two previous dimensions. Mediascapes pertain to the different kinds of media as well as the representations created by these media. Ideoscapes, on the other hand, also refer to a system of images; however, unlike mediascapes, ideoscapes are always political in nature. It should be noted that Appadurai's explanation about the dimensions of the global cultural flows is generally positive, with the influences of globalization working in constructive ways. Therefore, there is a need to mention his later work, Globalization (2001), in which he also discusses the concept of "grassroots globalization," an important concept that may decrease the disenfranchisement of the minorities in communities affected by globalization.

With all these theories in mind, this paper attempts to connect Appadurai's theories to explain the regional film The Chanters (Cena, Nazareno, Lapuz, \& Mayo, 2017). First, the paper will show the how the different "scapes" are presented in the movie, with focus on mediascapes and how they influence the main character as well as her view about her 
own native culture. Second, how the disenfranchisement of the natives and their cultures due to the phenomenon of globalization will be explained. Third, this paper will explain how the rural community, as seen through the film's main character, attempts to preserve and promote the indigenous culture by also using the influence of globalization. Finally, the paper returns to the idea of the regional space functioning like a rhizome, creating its own cultural productions and disregarding Manila-centric hierarchies, ultimately proving why the region is a necessary component of the nation.

\section{Generation Gap in the Era of Globalization}

James Robin Mayo's film The Chanters (Cena, Nazareno, Lapuz, \& Mayo, 2017) tells the story of Sarah Mae, a teenager who belongs to a chanting tribe of the Sulod society in Panay. She is a great fan of fictional telenovela star Danica Reyes, to the point that she volunteers to dance with her classmates for the opening number of the star's regional tour in her school. The enthusiasm Sarah Mae has for her idol is juxtaposed with her apathy for her own roots. Her grandfather Ramon, one of the living chanters of the tribe, serves as Sarah Mae's guardian because her mother is working as an OFW. The country that Sarah Mae's mother works in, as well as her occupation, is not mentioned in the course of the film's narrative.

The Sulod is a Philippine ethnic group in central Panay. F. Landa Jocano's monumental work about this ethnic group is detailed in his book Sulod Society: A Study in the Kinship System and Social Organization in the Mountain People of Central Panay (1968). Jocano gives a socioanthropological account of the Sulod ethnic group, with comprehensive descriptions about their origins, rituals, and way of life. According to him, the term Sulod is based on "what neighbors call their neighbors rather than what individuals call themselves" (p. 7). He added that the term is reflective of the geographical location of the tribe since Sulod means "'room,' implying a state of being 'enclosed', as by the tall mountains" (p. 8). The opening scene of the film hints at the geographical location of the tribe, as Sarah Mae and her grandfather Ramon, alighting from a bus coming from the village marketplace, still had to hop on a habal-habal, a motorcycle that can accommodate three or more people, to get to their home located somewhere in the lush, clustered barrios of Central Panay.

Jocano (1968) does not provide details about the chanting practices of the Sulod. These practices, though, are explained in the Philippine Epics and Ballads Archive of the Ateneo de Manila University by UP Visayas Professor Emeritus Alicia Magos, who led the transcriptions and English and Filipino translations from the original Kiniray-a language of the Sugidanon epics of Panay in 2014. In her article on the Sugidanon epics published, Magos 
(2019) stated that the term sugidanon comes from the Kiniray-a word sugid, which means "to tell" (p. 1). These epics are passed on from one generation to another through chanting, which was an important part of the ethnic group's culture.

In the foreword of Amburukay (2014), the second book of the Sugidanon epic, 2000 Gawad Manlilikha ng Bayan (GAMABA) awardee Federico Caballero noted that the practice of chanting of this Panay ethnic group has waned:

There was a time in the past when we thought the sugidanon would just fade away. Starting in the late 1960s, the transistor radio reached the interior mountain of Tapaz, Capiz. Those listening to the epic chants stopped listening to tune in to dramas heard on air. When the early 1970 s came (1971-1972), some barangays opened grades 1 and 2. Christianity (Roman Catholic) was also introduced, small chapels were built, and the priest would go up to the mountain to say mass during fiestas. Lowland music and stories were taught in schools. Later (1980s-1990s), our children would tell us not to chant anymore because it is wrong to chant and not good to hear, for it belongs to the bailan (shaman-curers). Even my own children would not like to listen. (p. xxix)

The exposure of the new generation to the contradictory aspects of tradition and modernity which are brought about by globalization causes important cultural productions such the Sugidanon chants to diminish and to ultimately be forgotten. Worse, the concept of globalization leans more on Western cultures which antagonize indigenous practices and privilege foreign cultures. The older generations who are more exposed to the ways of their specific tribes struggle to be recognized by the newer generations, who, instead of appreciating the culture that their ancestors have cherished, succumb to the alienating influences of Westernization.

The first few scenes of The Chanters (Cena, Nazareno, Lapuz, \& Mayo, 2017) already exhibit the conflict brought about by the contradictory influences that the two generations are exposed to. The millennial Sarah Mae is more interested in popular culture, while her grandfather embodies tradition. To highlight this, in the opening scene, the film shows a mise-enscène of Sarah Mae's cellphone placed on a brand-new selfie stick she bought with the money her mother sent them from abroad. Ramon complains that the purchase had been just a waste of hard-earned money and that she should have bought more useful things other than the selfie stick, but Sarah Mae insists that she loves her new purchase and continues to use it despite her grandfather's protests.

We see that Sarah Mae's actions are typical of teenagers. She takes a groupie with her friends using her selfie stick, and she is completely 
gaga over the primetime telenovela of a movie star named Danica Reyes, whose show Kiss Kiss Heart Heart is similar to that of the real primetime telenovelas in the Philippines. Sarah Mae's fanaticism is shared by the rest of her small and marginalized community, and every night they all watch Kiss Kiss outside the window of a generous neighbor who owns the only television set in town.

At work here in the film's first few scenes is Appadurai's (1990) concept of mediascapes, which is influenced by the growth of technoscapes. Appadurai defined technoscapes as the "global configuration, also ever fluid, of technology, and of the fact that technology, both high and low, both mechanical and informational, now moves at high speeds across various kinds of previously impervious boundaries" (p. 34). Technology is indeed one of the greatest aspects of globalization that changes the interaction between people and their society, since technology may be acquired by anyone nowadays. It controls businesses and even personal interactions.

Created by technoscapes is mediascapes, "both the distribution of the electronic capabilities to produce and disseminate information as well as the images of the world created by this media" (p. 35). In the film, the viewers can see the reach that the Manila-based networks have, and this influences the way that rural communities perceive themselves as a people as well. The remote town in which the film is set illustrates how the locality serves as a place for their culture to thrive, but its traditional ways have quickly changed because of the influence of globalization. The locals consume what the TV networks airing the telenovelas feed them. The images projected by these movies or telenovelas are often about the lives of the highly-urbanized middle class societies of Manila. Consequently, those from the rural areas begin to adapt the culture that the networks promote.

At work here is Althusser's ideological state apparatus (ISA), where mediascapes control the viewers through the images they present through the themes of their films or telenovelas, or even through various presentations posted in social media. As stated by Althusser (1971):

If the ISAs 'function' massively and predominantly by ideology, what unifies their diversity is precisely this functioning, insofar as the ideology by which they function is always in fact unified, despite its diversity and its contradictions, beneath the ruling ideology, which is the ideology of "the ruling class." (p. 245)

ISAs strengthen the power of the capitalists and puts the lives of the rural folk in the margins of society. This sweeping influence of mediascapes is seen in The Chanters (Cena, Nazareno, Lapuz, \& Mayo, 2017) in other 
scenes: Sarah Mae's entire school community is shown to be very excited about the visit of the enigmatic actress whose face is never seen in the film Kiss Kiss, and one of their hard-up neighbors is shown saving up money to buy a bigger television set so as not to miss an episode of the telenovela. In this light, mediascapes promote the dominance of urban culture, which leads to the decline of the rural area's rich cultures and traditions.

This leads to the kind of ideoscapes formed by the massive consumption of mediascapes. Ideoscapes has been defined by Appadurai (1990) as images which are "often directly political and frequently have to do with the ideologies of states and the counter-ideologies of movements explicitly oriented to capturing state power or a piece of it" (p. 36). Mediascapes, with its power and its reach, have a lot to do with the formation of ideologies, particularly about representations. As seen in The Chanters (Cena, Nazareno, Lapuz, \& Mayo, 2017), the community that watches their favorite telenovela only sees representations of the urbanized and often Manila-centric class, while representations of their own rural communities are often absent or misleading because these representations are often one-sided. Again, the mediascapes establish hegemony for the urbanized class, upholding its ideology, thereby depriving the rural community its voice.

The effect of representations done by mediascapes, which later lead to the formation of specific ideoscapes, is seen mostly through the character of Sarah Mae. In one of the earlier scenes in the film, she pays more attention to playing a game on her cellphone rather than to listening to her grandfather deliver a Sugidanon chant. In another scene, while Ramon teaches the young people the ancient chants of their tribe, Sarah Mae is busy decorating her native band, a piece of cloth usually tied to the waist, which she intends to give her favorite telenovela star as a gift when the latter visits their school. Another manifestation of Sarah Mae's apathy for her own tradition can be seen in the middle of the narrative when she takes her grandfather with her to keep him from wandering around because of his senility. Ramon uses the blackboard of an empty classroom to write the Sugidanon chant, which he religiously records for the NCCA in order to preserve his unique culture. Upon seeing her grandfather do this, she tells him that she might get reprimanded by her school teachers and quickly erases the epics that Ramon has written. The mise-en-scène showing Ramon continuously writing the chant on one end of the blackboard while Sarah Mae erases what he has previously written on the other side signifies how the new generation disregards cultural traditions and privileges Western influences. This ambivalence of young people about their own culture is also emphasized by the image showing the rural cultures being inferior in 
contrast with the urban, a misrepresentation propagated by the global reach of the mediascapes intending to maintain the rule of the urban class.

On the other hand, mediascapes may also be used not only for the urbanized class to maintain its rule but also for promoting the traditions of a specific community, particularly through the making of regional films. Fowler and Helfield (2006) discussed a similar type of regional film stemming from the tradition of thematically portraying the experiences of the rural folk. They asserted in their introduction to Representing the Rural Space: Place and Identity in Films about the Land:

While it is tempting to speak of the urban and rural in oppositional terms, they are inextricably linked as points of tension rather than points of contrast. Indeed, we can say that underlying all rural cinema is a contemporary consciousness that complicates yet also specializes its apparent attachment to the past, while at the same time drawing it nearer to the concerns of urban cinema: the expression of ongoing conflicts within a rapidly changing society or culture and the need to maintain a connection to a pure cultural or national identity, lost through urban assimilation and the dissipation or abandonment of rituals that in the rural context had kept this identity alive. (p. 3)

Fowler and Helfield's (2006) statement calls for a more accepting viewpoint eliminating the boundaries between the notion of the rural and the urban, because in the face of globalization, the relationship between these two terms becomes more complex. Rather on insisting on the hegemony of the urban practices, the advancement of local culture should be practiced. Magos (2019) said that this change of perspective from viewing the urbanized or Manila-centric culture as dominant has already been seen within the rural folk since the start of the new millennium. She said that informal, alternative schools that teach children the cultural heritage of chanting such as the one initiated by Ramon in the film are now being set up, and technology is already used by the rural folk to connect to the global community and promote their rich culture (p. 6).

\section{Mobility and Globalization}

The fourth aspect which defines a globalized community is its ethnoscapes, "the landscape of persons who constitute the shifting world in which we live" (Appadurai, 1990, p. 33). This is also related to Appadurai's concept of financescapes, which he referred to as the global capital transforming into "a more mysterious, rapid, and difficult landscape to follow than ever before" (p. 34), owing to the phenomenon of diaspora as well as the rapid growth of technoscapes. Two secondary characters which represent this 
aspect in The Chanters (Cena, Nazareno, Lapuz, \& Mayo, 2017) are Sarah Mae's mother and the fictional actress Danica Reyes.

Sarah Mae communicates with her mother, who is working abroad as an OFW, through her cellphone and uses her selfie stick to do so to get a better signal. While Ramon thinks that his granddaughter just wasted money, the stick actually serves a useful purpose. Like Sarah Mae's mother, Danica Reyes also figures minimally in the film, but she wields great influence within the community. All the film audience knows about her is through Sarah Mae's fanaticism; other than that, details about her telenovela are not fully divulged in the narrative.

Sarah Mae's mother and Danica Reyes both represent essential aspects of ethnoscapes. The mother represents the Filipino diasporic communities that also form distinct communities in their host countries. Danica represents the influence of the urban community on the rural. Both characters are agents of deterritorialization, defined as the factor that "brings laboring populations into the lower class sectors and spaces of relatively wealthy societies, while sometimes creating exaggerated and intensified senses of criticism or attachment to politics in the home state" (Appadurai, 1990, p. 37). Diasporic communities fragment and reorganize the idea of the family since one member of the family has to go abroad to ensure that the rest will live a better life. On the other hand, the power that urban culture has over rural space disengages the natives from appreciating and preserving their local cultures. These representations of ethnoscapes are also connected by the growth of capital, to the detriment of the traditions which are inherent in the local cultures. Culture is homogenized and commodified, following a more Westernized way of looking at it.

On the other hand, Stuart Elden (2004) has questioned the idea of globalization being always tied with deterritorialization. He noted the allembracing aspects of globalization, which is concerned with the world in totality. However, he said that there is a duality in the globalization process, which entails "first, the seizing or comprehending of a world as a whole; and second, the way in which political, economic, or cultural acts apply to that" (p. 9). Elden's statement means that the receivers of globalized influences may appropriate these into their own experiences and use them for the benefit of their own culture.

The Chanters (Cena, Nazareno, Lapuz, \& Mayo, 2017) shows this through several details in the film. When Ramon has gone missing, Sarah Mae, who has been spending a lot of time practicing for the opening number for Danica Reyes's tour, also realizes that she should take care of her grandfather and focus more on the preservation and appreciation of their diminishing culture. Knowing that the tour will have a lot of audiences, 
Sarah Mae uses this opportunity to present a contemporary version of the Sugidanon chant using the theme song of Kiss. Sarah Mae holds an audition in her neighborhood, calling her friends and other interested teenagers to perform with her. Although she herself is unable to make it to the performance because she had to look for her grandfather, her classmates are triumphant in letting those outside their community, represented by Danica Reyes, as well as the locals clueless about their cultural roots, realize the value of the Sugidanon chants.

The role of government institutions, which are primarily based in Manila, in preserving local cultures is also illustrated in the movie. Ramon is asked to transcribe the Sugidanon epics so that these could reach a larger audience and not just remain within the community. The dissemination of culture leads to its greater appreciation from people around the world.

\section{Conclusion: The Regional Film as a Positive Agent of Globalization}

The last few scenes of the film features mise-en-scènes of the Iloilo rural landscape-grass and flowers swaying in the wind, farmers peacefully working under the midday sun, children and rural folks smiling gleefullybefore ending with a scene where Sarah Mae looks straight into the camera. As the scene focuses on Sarah Mae, the narrow aspect ratio of the film expands. As the scene focuses on Sarah Mae, the narrow aspect ratio of the film expands, and a voiceover of Sarah Mae chanting a part of the Sugidanon epic is heard. The translation provided by the film is as follows:

The moment we all hesitate

Is the time we will vanish

Get close to me

I want to tell you something

There are words I want to leave, says Amburukay

What's the problem, she asks.

What's the matter?

I have to return to the wilderness, to the forest.

What more do you need?

You have a home.

You're alive.

Then, Amburokay pats her shoulder.

And embraces Uwang Matang-ayon lovingly.

I am only joking, Uwa. Believe me.

I am just joking.

Do not worry. 
I will go back home.

I promise. (Cena, Nazareno, Lapuz, \& Mayo, 2017, 1:09:32)

This excerpt is from Amburukay (Caballero \& Caballero, 2014), a part of the Sugidanon epic. It tells the story of the eponymous character, an enchanted woman who takes two children, Matan-ayon and Surangga-on, under her wing and turns them into binukot or kept maidens. Amburukay is also known to be an ugly woman who puts a curse on whoever steals her golden pubic hair-the thief will have to marry her. Her actual intention though is to marry off the thief to her adopted children.

Intermingling with this narrative is the story of Labaw Donggon, who breaks the string of his guitar, an heirloom he inherited. The only thing fit to replace the string is the golden pubic hair of Amburukay. Unaware of Amburukay's curse, he puts her to sleep using his magical powers then cuts her pubic hair. He is now bound to marry her. But on the day of their wedding, Labaw Donggon is transported to Amburukay's house only to find out that instead of the ugly maiden, the two lovely binukot brides are waiting for him.

The excerpt from Amburukay (Caballero \& Caballero 2014) used in the film becomes a metaphor for the importance of appreciating global cultures. In the excerpt, Amburukay wants to momentarily leave her home. One of her adopted children, Matan-ayon, questions this decision, saying that there is no reason for Amburukay to go back to the forest since the latter already has everything she needs. This part is suggestive of how we also intend to go back to our roots to appreciate the specific cultures of the regions because these are essential aspects that constitutes the idea of a nation. The Philippines, being a nation with a fragmented identity, should give utmost importance not only the culture of the city but also the cultures of the different regions in the country, since the collective idea of these cultures constitutes what Filipinos really are. The narrow aspect ratio of the film expanding in the film's conclusion also reminds us that Filipino regional culture should expand its reach by using the influences of globalization.

This diversity of Philippine culture, and ultimately, of the Filipino identity, lets us return to the growth of regional film being similar to that of a rhizome, as explained by Deleuze and Guattari (1987), and relate it to Appadurai's (1996) concept of global cultural flows. The increase of regional film production in different parts of the Philippines and the inclination to extend their reach globally could lead one to rethink the idea of Appadurai's (1996) mediascapes and ideoscapes and to put these in the context of grassroots globalization, which he also mentioned (2001). Philippine regional films bring the specific narratives of the Filipinos that had been 
voiceless before to a larger audience, thereby decentralizing globalization, which is often thought of as one-directional, that is, with only the Western world influencing the center and periphery. This progressive view of embracing what we call "films from the 'other' Philippines" (Groyon, 2014, p. 194) is a good start to remove the deeply entrenched colonial perspective that we have acquired in viewing even our very own cultural roots. It is about time that we see our world with our own native eyes. 


\section{References}

Aitouna, K., Dayoc, S., Micoulet, T., \& Thoke, C. (Producers), \& Dayoc, S. (Director). (2016). Women of the weeping river [Motion picture]. TBA Studios.

Althusser, L. (1971). On the reproduction of capitalism: Ideology and ideological state apparatuses (G.M. Goshgarian, Trans.). Verso.

Ang, A., Arguelles, R., \& Grande, P.G. (Producers), \& Vargas, P. (Director). (2016). 2 cool 2 be 4 gotten [Motion picture]. Cinema One Originals.

Appadurai, A. (1996). Modernity at large: Cultural dimensions of globalization. University of Minnesota Press.

Appadurai, A. (2001). Globalization. Durham: Duke University Press.

Arguelles, R., \& Balbuena, B. (Producers), \& Zuasola, R.S. (Director). (2014). Soap opera [Motion picture]. Cinema One Originals.

Arguelles, R., Borlasa, J. (Producers), \& Zuasola, R.S. (Director). (2010). Ang damgo ni Eleuteria [Motion picture]. Creative Programs, Inc.

Arguelles, R., \& Montelibano, M. (Producers), \& Somes, R. (Director). (2008). Yanggaw [Motion picture]. Creative Programs.

Barbarona, J.K., Barbarona, A., Macusang, N.D., Mardoquio, A., Mendez, E., \& Tolentino, R. (Producers), \& Barbarona, A. (Director). (2017). Tu pug imatuy [Motion picture]. Solar Pictures.

Caballero, F., \& Caballero, L. (2014). Amburukay: Sugidanon epic of Panay, book 2. (A. Magos, Trans.). University of the Philippines Press.

Campos, P. (2016). The end of national cinema: Filipino cinema at the turn of the century. University of the Philippines Press.

Canedo, D., \& Cejoco, C. (Producers), \& Mardoquio, A. (Director). (2012). Ang paglalakbay ng mga bituin sa gabing madilim [Motion picture]. Skyweaver Productions.

Cena, C., Nazareno, T., \& Lapuz, F. (Producers), \& Mayo, J.R. (Director). (2017). The chanters [Motion picture]. JMYO Productions.

Co, Teddy. (1987). “In Search of Philippine Regional Cinema." Movement 2 (1), 17-20.

De Leon, N. (Producer), \& Avellana, L. (Director). (1957). Badjao: The sea gypsies [Motion picture]. LVN Pictures.

Del Mundo, C., \& De Castro, R. (Producers), \& Del Mundo, I. (Director). (2014). K'na the Dreamweaver [Motion picture]. Tuko Film Productions.

Deleuze, G., \& Guattari, F. (1987). A thousand plateaus: Capitalism and schizophrenia. University of Minnesota Press.

Elden, S. (2005). Missing the point: Globalization, deterritorialization and the space of the world. Transactions of the Institute of British Geographers, 30(1), 8-19.

Factora, B., \& Petronas, G. (Producers), \& Cordero, K. (Director). (2016). Hinulid [Motion picture]. Cine Rinconada.

Fowler, C., \& Helfield, G. (2006). Representing the rural: Space, place, and identity in films about the land. Wayne State University Press.

Giddens, A. (1990). The consequences of modernity. Polity Press. 
Groyon, V. (2014). Cinemarehiyon 2009. In J. Chua, R. Cruz-Lucero, \& R. Tolentino (Eds.), A reader in Philippine film (pp. 177-196). University of the Philippines Press.

Hernandez, E.M. (2014). Digital cinema in the Philippines, 1999-2009. University of the Philippines Press.

How, M.O., \& Dulay, Z.M. (Producers), \& Dulay, Z. (Director). (2016). Paglipay [Motion picture]. Solar Pictures.

Jocano, F. L. (1968). Sulod society: A study in the kinship system and social organization in the mountain people of Central Panay. University of the Philippines Press.

Lapuz, F., Mendoza, C., Nepomuceno Jr., G., Aniceto, J., Tantingco, B., \& Baltazar, J. (Producers), \& Catu, C. (Director). (2015) Ari: My life with a king [Motion picture]. Center for Kapampangan Studies.

Magos, A. (2019). The Sugidanon (epics) of Central Panay. Philippine Epics and Ballads Archives of Ateneo de Manila University, 1-7. Retrieved from http://epics.ateneo.edu/epics/

Rapatan, M. (2017). Regional cinema: 1938-2014. In N. Tiongson (Ed.), CCP encyclopedia of Philippine art (Vol. 6: Film), (pp.82-91). Cultural Center of the Philippines.

San Juan Jr., E. (2000). Cinema of the "naïve" subaltern in search of an audience. In R. Tolentino (Ed.). Geopolitics of the visible: Essays on Philippine film cultures (pp. 264-276). Ateneo de Manila University Press. 


\section{Grant Support Details}

Author Contributions: All research activities and writing were done by Mary Anne Mallari. The author has read and agreed to the published version of the manuscript.

Funding: The author received no specific funding for this work.

Conflict of Interest: The author declares no conflict of interest.

\section{About the Author}

MARY ANNE MALLARI teaches literature at the University of Santo Tomas Senior High School. She is a PhD Literature candidate at De La Salle University. Her research focuses on bodies and spaces in Philippine cinema from the regions. (corresponding author: anne.mallari608@gmail.com) 
